\title{
Governmentality, social policy and the social construction of old age in England
}

\author{
Jason L. Powell \\ Faculty of Health \& Life Sciences, Coventry University, Priory Street, CV1 5FB, \\ Coventry, United Kingdom \\ E-mail address: jasonpwll3@gmail.com
}

\begin{abstract}
This article looks in more detail at the incidence and consequence of social policies for older people through the distinctly French post-structuralist lens of governmentality (Foucault, 1977). This will enable us to consider the implications of the re-figuring of the relationship between the state, older people and social work. This re-figuring constructs an ambiguous place for older people: they feature either as a resource - captured in the idea of the 'active citizen', as affluent consumers, volunteers or providers of child care - or as a problem in the context of poverty, vulnerability and risk. In many ways, policy provides three trajectories for older people: first, as independent self-managing consumers with private means and resources; second, as people in need of some support to enable them to continue to self-manage; and third, as dependent and unable to commit to self-management. Governmentality provides the theoretical framework through which to view policy and practice that is largely governed by discourses of personalisation, safeguarding, capability and risk.
\end{abstract}

Keywords: governmentality; ageing; power and self-management

\section{INTRODUCTION}

Let us begin the paper by stating that "old age" is not of itself a 'problem', 'pathology' or statement of need. 'Older people' are not a homogeneous group and categorisation as a distinct service user group is, arguably, contentious (Phillipson 2013; Chen and Powell, 2010). Furthermore, since the advent of personalisation in England, conceptualising support by user groups is considered by many as obsolete (Poll and Duffy 2008). People do not receive social services by virtue of being 'older'. Rather they are in need of a service - for example, because of ill health, physical impairment, mental health difficulties, addiction or offending.

This article looks in more detail at the incidence and consequence of social policies for older people through the distinctly French post-structuralist lens of governmentality (Foucault, 1977). This will enable us to consider the implications of the re-figuring of the relationship between the state, older people and social work. This re-figuring constructs an ambiguous place for older people: they feature either as a resource - captured in the idea of the 'active citizen', as affluent consumers, volunteers or providers of child care - or as a problem in the context of poverty, vulnerability and risk. In many ways, policy provides three trajectories for older people: first, as independent self-managing consumers with private means and resources; second, as people in need of some support to enable them to continue to self-manage; and third, 
as dependent and unable to commit to self-management. Governmentality provides the theoretical framework through which to view policy and practice that is largely governed by discourses of personalisation, safeguarding, capability and risk.

\section{DEMOGRAPHICS, POVERTY AND AGEISM}

Before moving on to assess governmentality and the construction of old age, it is highly pertinent to explore and problematise the notion of old age through consideration of demographics, poverty and ageism because these issues are intertwined with the way social policy targets both older people and those who work with them.

\section{(i) Demographics}

First we will consider demographics and some of the contradictions that lie within the figures. Much of the anxiety that surrounds the debate about old age concerns the proportion of the population that is older, non-economically productive and in some way dependent. In addition, changes in intergenerational family relations provoke concerns and anxiety over who has responsibility for supporting older people: the family or the state. Media hype fuels such concerns with suggestions that the costs of supporting an 'explosion' [sic] of older dependent people will overwhelm the ability of the reducing proportion of the population that is economically active and paying tax to fund the provision of care (Kemshall, 2002). In addition, a parallel argument suggests that the state is committing future generations to an unaffordable financial burden via pension payments and state-funded support. Such beliefs work to construct an image of older people as dependent and a burden on their children and the taxpayer and do much to fuel discrimination and ageism (Gilleard and Higgs, 2005).

It is correct that demographic changes are occurring with a reduction in the birth rate and an extension of life expectancy: projections suggest that there will be over 10 million people aged 65 and over by 2021 or; alternatively, that the over- $65 \mathrm{~s}$ will make up 17.2 per cent of the population (Phillipson, 2008). It is also the case that the over-65s are in percentage terms the highest users of health and social care services (Kemshall, 2002). Nevertheless, it is a cause for celebration that the last 25 years or so have seen progressive increases in life expectancy. In 2008 , approximately 8.3 per cent of the population were between 65 and 74, 5.8 per cent were aged $75-84$ and 2.2 per cent were 85 or older. 410,000 people were over 90 and 10,000 over 100 (Bayliss and Sly 2010). But despite the headline costs, only a small proportion of people in the older age bands require personal social services (Johnson, 1999). Many of us can look forward to an active and relatively healthy old age.

It is clear that predicting the future needs for support for specific individuals is more difficult in old age than in other periods of life. Nevertheless, the influence of major social variables such as class, race and gender continue to show a differential impact on morbidity and acquired limiting conditions, as well as on overall life expectancy. In particular, class-based differences show the influence of external factors from earlier parts of the life-course particularly pre- and post-natal periods and childhood (Kuh and Shlomo 2004) - a feature that Philp (2008) refers to as extrinsic ageing. This contrasts with intrinsic ageing which relates to the limitations of cells and other biological factors. At the same time, gender imbalances increase with age: there are 50 per cent more women than men aged 65 and over (Phillipson, 2008).

Race and ethnicity are factors in the differential impact of ageing on particular individuals. Again the links here are with earlier life experiences and extrinsic or environmental 
factors such as manual labour in risky settings, poverty, poor housing and racism (Phillipson, 2008).

In contrast, for some individuals and groups, the limitations associated with ageing come about at an earlier age, highlighting the problem of taking chronological age as the key determining factor. People with life-long disability tend to experience the 'effects' of ageing at an earlier part of the life-course. It is also well documented that some individuals - such as people with Down's Syndrome - have a higher risk of early onset Alzheimer type conditions (Bigby, 2004). There is also a growing recognition of early onset dementia and other organic cognitive impairments such as those linked to Crutzfeld-Jakob Disease (CJD) or, in certain cases, HIV/AIDS. Estimates suggest that there are some 16,000 people below the age of 65 with early onset dementia, with approximately 33 per cent having Alzheimer's Disease (Alzheimer's Society, 2011).

In addition to an awareness of these demographics, Kerr et al. (2005) suggests three contextual elements essential to effective social work with older people - poverty, ageism and the integration of services. We will consider the first two elements here and return to the issue of services later.

\section{(ii) Poverty}

Carroll Estes (1979) claims that poverty in old age is best understood in the relationship between ageing and the economic structure: that is, how the state decides and dictates who is allocated resources and who is not. This impinges upon social policy in relation to retirement and subsequent pension schemes. As Phillipson (1982) points out, the retirement experience is linked to the reduction of wages and enforced withdrawal from work; together, these place many older people in the UK in a financially insecure position.

Looking at the contemporary issue of poverty and older people, we have something of a mixed picture. Hoff (2008) notes the preference of policy makers from the late 1980s onwards to refer to the effects of poverty and social exclusion rather than just poverty. Walker and Walker (1997) highlight the need to take account of the multi-dimensional effects of low income and the impact of barriers to social integration experienced by older people. Nevertheless, there are contradictory patterns in income levels.

These demonstrate that despite a steep decline in pensioner poverty over the last decade of the $20^{\text {th }}$ century, at the turn of the $21^{\text {st }}$ century; nearly 25 per cent of British pensioners remained in poverty (DWP, 2005). In addition, early life experiences such as engagement in the labour market and decisions about investments and pensions impact on material resources in older age (Burholt and Windle, 2006).

Burholt and Windle (2006) emphasise the vulnerability of particular groups in older age: women, the socially disadvantaged, those from deprived neighbourhoods, people with ill health or disability, people living alone, divorced or widowed. They also note that, while individuals in younger generations may move in and out poverty, in later life there is little people can do about their position. Goldfield (2005) notes that deprived areas have a higher proportion of children and older people than wealthier areas.

\section{(iii) Ageism}

Hughes and Mtejuka (1992) identify personal, structural and cultural dimensions to ageism which they describe as the negative images and attitudes towards older people that are based solely on the characteristics of old age. Dominelli (2004) notes the complexity of the 
impact of social dimensions such as gender, race, disability, mental health and sexual orientation, in social work with older people. She claims that:

\begin{abstract}
'the negative image of the older person as dependant and in need of care portrays an ageist construction that treats every older person the same by ignoring the specific needs of older individuals and the contribution that older people as a group have made and continue to make to society' (Dominelli, 2004:137).
\end{abstract}

Thompson (2001) suggests that one manifestation of institutional ageism is the tendency for work with older people to be seen as routine and uninteresting, more suited to unqualified workers and social work assistants than to qualified social workers or nurses.

MacDonald (2004), describes a four year research programme about the priorities which older people themselves defined as important for 'living well in later life'. The older people involved in the projects did not commonly refer specifically to 'ageism', but the projects reported 'strong' evidence of its existence 'in a number of spheres'. These included poverty and the lack of opportunities that arise because much policy and practice identifies older people as a problem to be solved. She argues that, while older people continue to be viewed as a burden, then the denial of rights and opportunities to the ordinary things in life will continue.

\title{
3. GOVERNMENTALITY AND THE CONSTRUCTION OF OLD AGE
}

Exploring the role that social policy plays in shaping the social context of older people through the lens of governmentality is to adopt a specific approach to the analysis of this phenomenon. The use of such an analysis reflects the way that neo-liberal forms of government - such as those that have existed in the UK and most of the western world since the late $20^{\text {th }}$ century - manage populations. Our interest is in the subtle mechanisms through which the behaviour of individuals is shaped, guided and directed without recourse to coercion (Foucault 1991, Rose 1999). Central to this process is the concept of the self-managing citizen-consumer engaged in an endless process of decision-making in consumer-based markets. The process is supported by an array of discourses of self-management and associated social practices that are disseminated through social institutions such as factories and workplaces, the media, banks and retail outlets, health and welfare services, schools and universities, churches, and leisure and community organisations.

These discourses penetrate deep into family life and personal relationships, regulating behaviour by locating individuals in a network of obligations towards themselves and others. Simultaneously a 'felt' responsibility for a particular locality or an imagined community is produced (Rose 1996), whereby identity is affirmed. Examples of this process can be identified in the commitments to promoting social capital of the Blair/Brown Labour administrations or the 'Big Society' idea of the Cameron/Clegg Coalition government. Citizenship is avowed by participating in consumer-based activities and the maintenance of an accredited life-style (Miller 1993). The process has been described as an 'ethic of the self' (Davidson, 1994) and is supported by an ever increasing array of experts embedded in a range of social systems such as physicians, health professionals, social workers, beauticians, personal trainers and financial advisers (Rose 1999).

Parallel to this process the state is concerned with gathering statistics that help define the population and maintain a level of surveillance that affords the management of risk. Affluent older persons are identified, measured, and then grouped with similar persons. Once described, 
the characteristics of this group are disseminated via a range of media that suggest personality, aspirations and life chances. Similarly, older people requiring support - the physically infirm, cognitively impaired, widowed etc - are identified, measured, grouped and their characteristics disseminated. For most individuals the level of surveillance is best described as a light touch sufficient to maintain the disciplinary focus of the state in a way that is both fleeting and total (Rose and Miller 1992, Rose 1996, 1999, Turner 1997, Knowles 2001). However, for those whose behaviour is thought to be high risk or for those who fail to conform to the notion of the self-managing consumer-citizen, this surveillance is more oppressive, leaving them vulnerable to victim-blaming (Osborne 1997). This produces the three trajectories referred to earlier where those individuals who are willing and able to commit to the market and to self-manage experience a particular combination of options and opportunities while those who, for whatever reason, fail to meet this commitment experience a different and more limited set of options that are often oppressive and impersonal (Rose, 1996; 1999; Petersen, 1997; Gilleard and Higgs 2005). The consequence of this for the 'government of government' (cf. Foucault 1977) is that its role is clearly circumscribed. It must set out to ensure that basic freedoms are respected, but acknowledge the importance of the family and the market for the management of the care of older people.

\section{SOCIAL POLICY: CONSTRUCTING THE CONTEXT}

We can now explore how policy constructs what might be described as the social context of older people: how older people are identified and separated first from each other ('affluent' versus 'frail and dependent') and then from the rest of the population. Consequentially, they are then targeted by specific policies which, in turn, construct practices and services for this section of the population. For older people the policy initiative that had the greatest impact was the introduction of state pensions during the Edwardian period, implemented by the Old Age Pensions Act 1908 (Phillipson 1998). Although this was means-tested, it did prevent people aged 70 or older having to seek refuge in the workhouse, and paved the way for a pension system based on the insurance principle, following on from the passing of the first national insurance legislation in 1911. In a sense, the limitations of the scheme were not so important as the beginnings of the break with Liberalism and the symbolic move towards the provision of more state support for older people, which supplanted punitive measures. This was further reinforced by the introduction of the welfare state in 1945 and the idea of citizenship based on a set of social as well as political and legal rights (Marshall, 1950) which meant that people no longer had to rely on a myriad of local charitable organisations, the churches and the Poor Law. In the process, this led to an expansion of state provided services many of which were managed by local authority departments.

Analysing the impact of neo-liberalism from different perspectives, both Giddens (1998) and Beck (2005) have claimed that citizens and the state are faced with the task of navigating themselves through a changing world in which globalization has transformed personal relations and the relationship between state and the individual. In the period since 1979, both Conservative and Labour Governments have adopted a neo-liberal stance characterised by an increasing distancing of the state from the direct provision of services. Instead, government operates through a set of relationships where the state sets standards and budgets for particular services but then contracts delivery to private, voluntary or third sector organisations. The underpinning rationale is that this reconfiguration of the state retains a strong core to formulate public policy alongside the dissemination of responsibility for policy implementation to a wide 
range of often localised modes such as social work and social workers. Neo-liberal governance emphases enterprise as an individual and corporate strategy, supported by its concomitant discourse of marketisation and the role of consumers. The strategy increasingly relies on individuals to make their own arrangements with respect to welfare and support, accompanied by the rhetoric of choice, self-management, responsibility and obligation (Jordan, 2005) - even where public money is used to pay for services.

Neo-liberalism in the 21 st century is perhaps the dominant contemporary means through which boundary adjustments are being made and rationalised, with far-reaching consequences for both states and markets. The project of neo-liberalism is evolving and changing, while the task of mapping out the moving terrain of boundaries for social work and older people's experiences is only just beginning; it is long overdue. In this context, the territorial state defined by geographical space is not so much withering away as being increasingly enmeshed in webs of economic interdependencies, social connections and political power. This, in turn, leads to the development of a denser and more complex set of virtual, economic, cultural and political spaces that cut across traditional distinctions between inside and outside, public and private, left and right (Beck, 2005). In this sense, possibly the most influential piece of contemporary neo-liberal social policy came with the implementation of the National Health Service and Community Care Act, 1990. This brought with it the purchaser/provider split and case management; it laid the foundations for subsequent policy initiatives such as the cash-for-care schemes (Direct Payments and Individual Budgets) which provide the core of the 'personalisation agenda'. Much of this is inspired by global developments in the way care is funded (Powell \& Gilbert, 2011).

In the second decade of the $21^{\text {st }}$ Century, we have entered an accelerated phase of retraction by the UK state in relation to its role in the provision of welfare, with actual levels of support being reduced. Rhetorically, the Conservative/Liberal Democrat coalition is committed to the idea of the 'Big Society' which translates into a vision of individuals and communities coming together to work to resolve common concerns, as this Cabinet Office statement confirms:

We want to give citizens, communities and local government the power and
information they need to come together, solve the problems they face and
build the Britain they want. We want society - the families, networks,
neighbourhoods and communities that form the fabric of so much of our
everyday lives - to be bigger and stronger than ever before. Only when people
and communities are given more power and take more responsibility can we
achieve fairness and opportunity for all. (The Cabinet Office
2010 , www.cabinetoffice.gov.uk/news/building-big-society accessed $08 / 04 / 2011)$

This 'felt responsibility' for a particular locality or 'imagined community' is core to the neo-liberal project which, alongside active citizenship, provides the discursive structure for volunteering and the promotion of a network of voluntary activity. In the process, the disciplinary effect of the self-managing individual is reproduced at neighbourhood and community levels. The third sector is crucial in such a scenario, playing a key role by interconnecting a new partnership between government and civil society. Promoting this relationship is core to the functions of the new Office of Civil Society established by the coalition government in 2010 whose role is to enable people to develop social enterprises, voluntary and charitable organisations while promoting the independence and resilience of the sector. 
Evidence of public intervention to support the renewal of community through local initiatives not only advances the status of professional social work organisations but fetishises the day-to-day operations of social work. Equality, mutual respect, autonomy and decisionmaking through communication with socially disadvantaged and/or dependent older people come to be seen as integral to the sector and provide an opportunity to encourage socially excluded groups and communities to participate as active citizens in, rather than be seen as a potential burden to, community engagement (Gilleard and Higgs, 2005). Neo-liberalism is especially concerned with inculcating a new set of values and objectives orientated towards incorporating citizens as both players and partners in a marketized system. As such, social workers are exhorted to become entrepreneurs in all spheres and to accept responsibility for the management of civic life (Beck, 2005). There is also an apparent dispersal of power (Foucault, 1977) achieved through establishing structures in which social workers and older people are co-opted into or co-produce governance through their own accountable choices (Gilbert and Powell 2010).

As Burchell (1993) has observed, this is directly connected with the political rationality that assigns primacy to the autonomization of society in which the paradigm of enterprise culture comes to dominate forms of conduct including that of social work with older people. The very significance of autonomization is that there is a strategic aim to diffuse the public sector's monolithic power to encourage diversity and fragmentation of provision of care to private and voluntary sectors. Such a strategy constitutes a fundamental transformation in the mechanisms for governing social life. It has combined two interlinked developments: a stress on the necessity for enterprising subjects and the resolution of central state control with older people articulates with a desire to promote organizational social work autonomy through service provision. Each of these has redefined previous patterns of social relationships within and between those agencies and their clients.

The important point to note is that there is great contingence and variation in such relationships, with unevenness across time and space. These relationships involve the development of new forms of statecraft - some concerned with extensions of the neo-liberal market-building project itself (for example, trade policy and financial regulation), some concerned with managing the consequences and contradictions of marketisation (for example, social policy). It also implies that the boundaries of the state and the market are blurred and that they are constantly being renegotiated (Kendall, 2003). Theoretically we identify the need to engage with key social debates about the future of welfare and individual relationships to and expectations of the state. One of the central debates has been on neo-liberalism and its impingement on re-positioning of older people and collective organisation of modern society.

\section{INTEGRATING SERVICES: SOCIAL POLICY AND OLDER PEOPLE}

The previous sections of this article have sought to identify the changing relationship between the state and older people by exploring the notion of governmentality. The discussion now moves on to consider more specifically how social policy shapes the social context for older people. Here we need to take account of the social and economic backdrop that frames older people's experiences of support and care. In the process, we identify key developments in social policy such as personalisation, risk and safeguarding, and their congruence with the neo-liberal project. The neo-liberal project constructs as its core subject the self-managing citizen-consumer who is actively making choices within markets. In the context of welfare this involves individuals making choices about the type of support they want and who will provide 
that support as the range of providers is expanded in two broad ways. First, new providers enter the market providing new services or providing services in new ways. Second, and of key importance, people seeking support move outside of the segregated confines of welfare services to obtain services from mainstream providers (Dickinson and Glasby, 2010). Such innovative moves may include, for example, a physical exercise programme from a sports centre instead of physiotherapy, an art course instead of time at a day centre, a holiday abroad instead of respite care.

In many ways, the 'Personalisation Agenda' as it is set out in 'Putting People First' (2007) represents the high point of the neo-liberal project with respect to welfare. This approach is largely constructed through a framework of earlier policy which includes the Community Care (Direct Payments) Act (1996), Independence Wellbeing and Choice (DH, 2005) and Our Health, Our Care, Our Say (DH, 2006). This was then supplemented by the Coalition Government with the publication of Capable Communities and Active Citizens (DH, 2010) and Think Local, Act Personal (2011) which aim to tie the shift to self-directed support outlined by the 'Personalisation Agenda' more closely to the notion of the Big Society. The discourses that articulate within this policy framework are those familiar to neo-liberalism: independence, choice, freedom, responsibility, quality, empowerment, active citizenship, partnership, the enabling state, co-production and community action.

Alongside this policy framework are constructed a number of specific techniques that target individuals, families and communities. These include an alternative method of allocating cash to individuals in the form of individual budgets, on-line self-assessment to augment local authority assessment processes, and community-based advocacy to support life style choices. In addition, commissioning models and approaches are being developed that aim to promote opportunities by responding proactively to the aspirations of people receiving services. Selfdirected support is significant as it breaks with the tradition where state support is mediated by professionals who undertake assessments and organisations that are funded to provide places. Even in more recent times, when individuals might be afforded a choice between two or more places or opportunities, the organisations received funding from the state. Under personalisation, assessment takes place to identify the overall budget a person is entitled to receive, but the money is allocated to the individual either through a direct payment or by establishing an individual budget. In terms of governmentality, the 'Personalisation Agenda' effectively shifts the responsibility for organising support from the state to the individual needing support via a form of cash transfer - something that Ferguson (2007) describes as the privatisation of risk.

The advance of the 'Personalisation Agenda' has drawn support from a number of sources including specific groups of service users (Glendinning et al. 2008), politicians from across the spectrum (Ferguson 2007), and social care managers and social workers (Samuel, 2009). One possible reason for this is that personalisation is conceptually ambiguous, making it difficult to disagree with its basic premise while it retains a number of contradictory ideas (Ferguson, 2007). However, it has also drawn criticisms particularly from older people who have reported lower psychological wellbeing due, possibly, to added anxiety and stress due to the burden of organising their own care (Glendinning et al. 2008). There are also concerns expressed regarding the impact of personalisation on the integration and stability of adult social care; this includes unease with the emphasis on individualistic solutions which may undermine democratic and collective approaches to transforming existing services or developing new services (Newman et al. 2008). Doubts have also been expressed over the readiness of the third sector to take on the demands of providing support. At the same time, while the disaggregation of budgets might suit some small innovative niche organisations the disruption of funding 
streams may be perceived as a threat and bring instability to larger more mainstream third sector organisations (Dickinson and Glasby, 2010). Other issues arise due to the somewhat fragmented process of implementation and the differences that occur in service provision between urban and rural areas (Manthorpe and Stevens, 2010). Ferguson (2007), drawing on the Canadian experience, suggests that personalisation favours the better educated, may provide a cover for cost-cutting and further privatisation and marketization of services, while the employment conditions of personal assistants may give rise to concern.

Governmentality enables the identification of the parallel concerns of neo-liberalism - the promotion of the self-managing individual and the management of risk. So far we have explored self-management in social care through the promotion of self-directed care as part of the 'Personalisation Agenda'. We now turn to the management of risk. This can be seen to take two forms, each dealt with by different elements of social policy. Protection from the risks posed by others are managed through safeguarding and policy such as No Secrets (DH and HO, 2000) [England and Northern Ireland] or In Safe Hands (2000) [Wales]. In Capable Communities and Active Citizens (2010) the government clearly states that safeguarding is central to personalisation. Risks posed by the individual to their own person are contained by the Mental Capacity Act (2005) and its powers to override individual choice or replace autonomy by measures such as Enduring or Lasting Powers of Attorney or the Court of Protection.

No Secrets has provided the basis of policy towards safeguarding for over a decade. It defined abuse in the context of an abuse of trust and the Human Rights Act (1998) and set out a model for inter-agency working that has been adopted by local authorities in England and Northern Ireland. In Wales the corresponding policy is 'In Safe Hands'. No Secrets drew from experience in relation to safeguarding children and described a number of categories of abuse including physical, sexual, neglect and financial abuse. However, it lacked the legal imperative to share information that is included in safeguarding children. Furthermore, the environment within which 'No Secrets' operates has seen considerable change since implementation. One key change was the discursive shift from vulnerable adult to safeguarding that took account of the dangers of victim blaming implied in the notion of vulnerable adults while the concept of safeguarding suggests the focus should be on the environment within which people find themselves. However, this rhetorical shift has not removed abuse. A recent prevalence survey suggests levels of abuse of between 2.6 per cent and 4 per cent, depending on how the estimates are constructed (O'Keeffe et al. 2007). Action on Elder Abuse, one of the organisations that sponsored the study uses evidence of under reporting to reinterpret this estimate as 9 per cent (Gary Fitzgerald, personal communication).

In 2008, the Department of Health set up a consultation over the review of No Secrets where a number of organisations including the Association of Directors of Adult Social Care and Action on Elder Abuse campaigned for a legislative framework to put adult protection on the same footing as child protection (Samuel, 2008). However, no significant changes in guidance or legal status occurred as the Coalition government maintained that safeguarding was an issue for local communities; thus maintaining the distance between the state and individuals. Discourses of safeguarding operate and produce their effects via the multiple interactions of institutions embedded in local communities. Furthermore, the advent of personalisation has seen an increasing focus on financial abuse as direct payments and rules about eligibility for state support for care costs increase opportunities for financial exploitation, fraud and theft. No Secrets treats financial abuse as an artefact of other apparently more serious forms of abuse. However, in 2004, the House of Commons Select Committee identified financial abuse as possibly the second most commonly occurring form of abuse experienced by older people. 
Estimates in the USA suggest that financial abuse is the most common form of abuse with up to 40 per cent of older people victims (Gorbien, 2011).

\section{CONCLUSIONS}

This article has explored the place that social policy plays in shaping the social context of older people. To achieve this we have drawn on the concept of governmentality to identify how neo-liberal forms of government construct older people as active consumers within welfare markets shifting the responsibility for organising support from the state to the individual. The contemporary context for working with older people who need some form of support is formed by the relationship between personalisation and safeguarding. These set out the twin pillars of neo-liberal governance, namely self-management through self-directed support and the management of risk through safeguarding. Individuals are constructed as citizen-consumers actively making choices about what their needs are and identifying appropriate services, sometimes with the support of advocates or workers such as social workers in a process of coproduction. In circumstances where risks are considered too high the power to make choices can be temporarily or permanently restricted.

\section{BIOGRAPHY}

Professor Jason L. Powell BA (Hons), MA, Ph.D, FRSA is Professor of Social Gerontology and Associate Dean of Faculty of Health and Life Sciences at University of Coventry. He holds an Honorary Fellowship at University of Liverpool; Honorary Professor at Australia-Asia Research and Education Foundation at Tasmania University; Visiting Research Fellow at Oxford; and recently invited as Visiting Scholar at Harvard University. He has been Visiting Professor in Canada, US, Australia, Africa and Jordan. He was nominated and elected to Fellowship of the British Royal Society of Arts (FRSA) in recognition of his research. He has strong interests in social theory, ageing, power and identity. He is author of Social Theory and Ageing (2006) which was part of Charles Lemert's distinguished 'New Social Formations' book series, Rowman and Littlefield: New York.

\section{References}

[1] Alzheimer's Society. (2011). What is Dementia: Factsheet 400. http://www.alzheimers.org.uk accessed 12/04/2011.

[2] Bayliss, J \& Sly, F. (2010). Ageing across the UK. Newport: Office of National Statistics.

[3] Beck, U. (2005) Power in the Global Age. Cambridge: Polity Press.

[4] Bigby, C. (2004). Ageing with a Lifelong Disability. London: Jessica Kingsley.

[5] Burchell, G. (1993). Liberal government and techniques of the self, Economy and

[6] Burholt, V \& Windle, G. (2006). The material resources and well-being of older people. York: Joseph Rowntree Foundation.

[7] Davidson, A, I. (1994). Ethics as ascetics: Foucault, the history of ethics, and ancient thought. In Gutting, G. [ed.] The Cambridge Companion to Foucault. Cambridge University Press: Cambridge pp. 115-140.

[8] Department of Health (1996). Community Care (Direct Payments) Act. London: TSO. 
[9] Department of Health (2005). Independence Wellbeing and Choice: Our vision for the future of social care for adults in England. London: TSO.

[10] Department of Health (2006). Our Health, Our Care, Our Say: A new direction for community services. London: TSO.

[11] Department of Health (2007) Putting People First: Shared vision and commitment to the transformation of adult social care. London: TSO.

[12] Department of Health (2010). A Vision for Adult Social Care: Capable Communities and Active Citizens. London: TSO.

[13] Department of Health (2011). Think Local, Act Personal: A sector wide commitment to moving forward with personalisation and community based support. London: TSO.

[14] Department of Health and Home Office (2000). No Secrets: guidance on developing and implementing multi-agency policies and procedures to protect vulnerable adults from abuse. London: TSO.

[15] Department of Health and Social Security (1990). National Health Service and Community Care Act. London: TSO.

[16] Department of Work and Pensions (DWP) (2005). Older people in low-income households. London: TSO

[17] Dickinson, H. \& Glasby, J. (2010). The personalization agenda: implications for the third sector. Third Sector Research Centre: Working paper 30. Birmingham: TSRC

[18] Dominelli, L. (2004). Theory and Practice for a Changing Profession. Cambridge: Polity Press.

[19] Estes, C. (1979). The Aging Enterprise. San Francisco: Jossey Bass. Evaluation of Individual Budgets. London, Department of Health. Evaluation of the Individual Budgets Pilot Programme: Final Report. Social Policy Research Unit, University of York, York.

[20] Ferguson, I. (2007). Increasing User Choice or privatizing Risk? The Antinomies of Personalization. British Journal of Social Work, 37(3): 387-403.

[21] Foucault, M. (1977). Discipline and Punish. London: Allen Lane.

[22] Foucault, M. (1991). 'Governmentality', in Burchell, G., Gordon, C. and Miller, P. [eds.], The Foucault Effect: Studies in Governmentality. Hemel Hampstead: Harvester Wheat sheaf.

[23] Giddens, A. (1998). The Third Way: The Renewal of Social Democracy. Cambridge: Polity Press.

[24] Gilbert, T \& Powell, J, L. (2010). Power and Social Work in the United Kingdom: A Foucauldian Excursion. Journal of Social Work 10(1): 3-22.

[25] Gilleard, C. \& Higgs, P. (2005). Contexts of Ageing: Class, Cohort and Community. Cambridge: Polity Press.

[26] Goldfield, T. (2005). Wealth of the Nation 2005. Brighton: CACI.

[27] Gorbien, M. (2011). Protecting Against fraud and Financial Abuse. Chicago, Illinois: Rush University Medical Center. 
[28] HM Government (2010). The Cabinet Office: The Big Society www.cabinetoffice.gov.uk/news/building-big-society accessed 08/04/2011)

[29] Hoff, A (2008). Tackling Social Exclusion of older People - lessons from Europe. Working paper 308, Oxford: Oxford Institute of Ageing/University of Oxford

[30] House of Commons Health Select Committee. Elder Abuse (2004). Second Report of Session 2003-4 Vol. 1. Report, together with formal minutes. London: TSO.

[31] Hughes, B. \& Mtejuka, E, M. (1992). Social Work and Older Women, in M, Langan \& L, Day [eds.]. Women, Oppression and Social Work: Issues in anti-discriminatory practice. London: Routledge.

[32] Johnson, N. (1999). The personal social services and community care, in M, Powell [ed.] New Labour, New Welfare? The 'Third Way' in British Social Policy. Bristol: Policy Press.

[33] Jordan, B. (2005). New Labour: Choice and values. Critical Social Policy, 25(4): 427-446.

[34] Jordan, B. with Jordan, C. (2000). Social Work and the Third Way: Tough love as social policy. London, Sage.

[35] Kemshall, H. (2002). Risk, Social policy and Welfare. Buckingham: Open University Press.

[36] Kendall, J. (2003). The Voluntary Sector: Comparative perspectives in the UK. London: Routledge.

[37] Kerr, B., Gordon, J., MacDonald, C. \& Stalker, K. (2005). Effective Social Work with Older People: A paper prepared for the Scottish Executive. Stirling: Social Work Research Unit, University of Stirling.

[38] Knowles, C. (2001). Cultural perspectives and welfare regimes: The contributions of Foucault and Lefebve, in P, Chamberlayne., A, Cooper. \& M, Rustin [eds.] Welfare and Culture in Europe: Towards a New Paradigm in Social Policy. London: Jessica Kingsley pp. 240-254.

[39] Kuh, D. \& Shlomo, B, Y. (2004). A Life Course Approach to Chronic Disease Epidemiology. Oxford: Oxford University Press.

[40] MacDonald, C. (2004). Older People and Community Care in Scotland: A review of recent research. Edinburgh: TSO.

[41] Manthorpe, J. \& Stevens, M. (2010). Understanding the potential impact of personalization for social work with rural older people. British Journal of Social Work, 40(5): 1452-1469.

[42] Marshall, T. H. (1950). Citizenship and social class and other essays. Cambridge: Cambridge University Press.

[43] Mental Capacity Act (2005). London: TSO.

[44] Miller, T. (1993). The Well-Tempered Self: Citizenship, Culture and the Postmodern Subject. Baltimore: John Hopkins University Press. 
[45] Newman, J., Glendinning, C. and Hughes, M. (2008) 'Beyond modernisation? Social care and the transformation of welfare governance', Journal of Social Policy, 37(4): 531-557.

[46] O'Keeffe, M., Hills, A., Doyle, M., McCreadie, C., Scholes, S., Constantine, R., Tinker, A., Manthorpe, J., Biggs, S., \& Erens, B. (2007) UK Study of Abuse and Neglect of Older People: Prevalence Survey Report. Prepared for Comic Relief and the Department of Health. London: National Centre for Social Research/King's College London.

[47] Ogg, J. (2005). Social exclusion and insecurity among older Europeans: the influence of welfare regimes. Ageing \& Society, 25: 69-90.

[48] Osborne, T. (1997). Of Health and Statecraft, in A, Petersen. \& R, Bunton [eds.] Foucault: Health and Medicine. London: Routledge pp. 173-188.

[49] Petersen, A. (1997). Risk, governance and the new public health, in A, Petersen. \& R, Bunton [eds.]. Foucault: Health and Medicine. London: Routledge pp. 189-206.

[50] Phillipson, C. (1982). Capitalism and the Construction of Old Age. Basingstoke: Macmillan.

[51] Phillipson, C. (1998). Reconstructing Old Age: New agendas in social theory and practice. London: Sage.

[52] Phillipson, C. (2008). The Frailty of Old Age, in M, Davies [ed.] The Blackwell Companion to Social Work [ $3^{\text {rd }}$ Edition]. Oxford: Blackwell Publishing.

[53] Phillipson, C (2013). Ageing Bristol: Policy Press.

[54] Philp, I. (2008) Late Life Ageing, in M, Davies [ed.] The Blackwell Companion to Social Work [ $3^{\text {rd }}$ Edition]. Oxford: Blackwell Publishing.

[55] Poll, C \& Duffy, S. [eds.] (2008) Report of In Control's Second Phase 2005 - 2007. London: In Control Publications.

[56] Powell, J, L. \& Gilbert, T. (2011) Personalisation and Sustainable Care. Journal of Care Services Management, 5(2): 79-86.

[57] Rose N. (1996). The death of the social? Re-figuring the territory of government. Economy and Society, 25(3): 327-356.

[58] Rose N. (1999). Powers of Freedom: Reframing political thought. Cambridge: Cambridge University Press.

[59] Rose, N., and Miller, P. (1992). Political power beyond the state: problematics of government. British Journal of Sociology, 43(2), 173-205.

[60] Samuel, M. (2008) No Secrets Review: The key issues. Community Care 20/02/2008.

[61] Samuel, M. (2009). Practitioners back personalisation but call for more support. Community Care18/03/2009. Society, 22(3), pp. 267-82.

[62] The National Assembly for Wales and the Home Office (2000) In Safe Hands: Implementing Adult Protection Procedures in Wales. Cardiff: The National Assembly for Wales.

[63] Thompson, N. (2001). Anti-Oppressive Social Work Practice. Basingstoke: Palgrave. 
[64] Turner, B, S. (1997). From governmentality to risk: Some reflections on Foucault's contribution to medical sociology, in A, Petersen. \& R, Bunton [eds.] Foucault: Health and Medicine. Routledge: London. pp ix-xxi.

[65] Walker, A. \& Walker, C. (eds.): (1997). Britain Divided. London: CPAG. 